International Journal of Child, Youth, and Family Studies (2014): 5(4.1) 605-610

\title{
INTRODUCTION TO THE SPECIAL ISSUE ON INVOLVING CHILDREN AND YOUNG PEOPLE IN RESEARCH
}

\author{
Cara Blaisdell, Jeni Harden, and E. Kay M. Tisdall
}

Cara Blaisdell is a Ph.D. student in Social Policy at the University of Edinburgh, SPSS CMB, 15A George Square, Edinburgh, United Kingdom, EH8 9LD.

E-mail: c.b.blaisdell@sms.ed.ac.uk

Jeni Harden, Ph.D. is a Senior Lecturer at the Centre for Population Health Sciences and Co-Director of the Centre for Research on Families and Relationships, at the University of Edinburgh, Teviot Place, Edinburgh, United Kingdom, EH8 9AG. E-mail: jeni.harden@ed.ac.uk

E. Kay M. Tisdall, Ph.D. is Professor of Childhood Policy and Co-Director of the Centre for Research on Families and Relationships, at the University of Edinburgh, SPSS CMB, 15A George Square, Edinburgh, United Kingdom, EH8 9LD.

E-mail: k.tisdall@ed.ac.uk

The status of children and young people in social research has been a key area of debate since the emergence of the "new" sociology of childhood in the late 1980s and early 1990s. Sparked initially by work in sociology and anthropology, the sociology of childhood rapidly spread to become an interdisciplinary area of interest, now commonly referred to as "childhood studies", to recognize its increasing multi-disciplinary spread (Punch \& Tisdall, 2012). With the emergence of this paradigm, new ways of conceptualizing and theorizing childhood were linked to changes in how research with children and young people was conducted. Researchers considered how their own understandings of childhood, constructed by "culturally and historically specific beliefs and assumptions” (Harden, Scott, Backett-Milburn, \& Jackson, 2000, 2.4), affected the way they engaged with children and young people in the research context. The concept of children's agency was enthusiastically adopted by the nascent childhood studies community (James \& Prout, 1997) and underpinned attempts to allow children and young people a "more direct voice and participation" (Prout \& James, 1997, p. 8) in research about their lives. This agenda stood in contrast to historic - and cross-disciplinary research practice, which relied on the perspectives of adult researchers, professionals, or parents (Woodgate, 2001). There were also strong links with a children’s rights 
International Journal of Child, Youth, and Family Studies (2014): 5(4.1) 605-610

perspective, a core element of which is children and young people's "right to be heard" (United Nations [UN] Committee on the Rights of the Child, 2009).

Over time, it has increasingly become routine for children and young people to be involved more directly in social research, in ways that go beyond them being the objects of study. Simultaneously, childhood researchers have identified benefits, limitations, and tensions that arise from this involvement. Overlapping issues include: the utility and necessity of using specific methods when researching with children and young people (Mauthner, 1997; Punch, 2002; Thomson, 2007); the stages of research in which children and young people are invited to participate (Coad \& Evans, 2008; Davis, 2009; Kellett, 2010); and ethical issues, including, for example, the impact - or lack thereof - of children and young people's participation in research on the conditions of their daily lives (Alderson \& Morrow, 2011; Davis 2009; Percy-Smith 2006). Discussion of these issues has been underpinned by an ongoing consideration of how researchers themselves view both childhood and adulthood. In particular, the emphasis on children as agents has been critiqued for reinforcing "the myth of the autonomous and independent person" (Prout, 2005, p. 66), which itself is tied to dichotomous, mutually exclusive conceptualizations of what it means to be a child or an adult (Gallacher \& Gallagher, 2008; Prout, 2005, 2011; Uprichard, 2008). New trends in contemporary childhood studies have moved toward exploring the role of interdependence and relational processes between adults and children (Mannion, 2007; Mayall, 2012; Prout \& Tisdall, 2012).

\section{Overview of the Special Issue}

We are pleased, therefore, to contribute to the ongoing discussion with this special issue of the International Journal of Child, Youth and Family Studies. For this issue, authors were asked to examine critically the direct involvement of children and young people in their research. While each paper is inextricably linked to the method(s) used, the articles go beyond technical advice, weaving together practical, epistemological, and ethical considerations.

The six articles presented in this issue arose from the International Conference of the Centre for Research on Families and Relationships (CRFR), held at the University of Edinburgh in June 2013. The conference theme was "Researching families and relationships: innovations in methods, theory and policy relevance”. Over three days, 122 delegates from over 20 countries came together to discuss contributions from research, policy, and practice perspectives.

To guide contributions to the special issue, we provided a broad set of questions, hoping to push forward methodological considerations in childhood research:

- After 20 or so years of involving children and young people as "social actors" in research, what are the tough questions we need to ask?

- What accepted practices do not live up to their presumed advantages?

- What role do new technologies have in researching with children and young people? 
International Journal of Child, Youth, and Family Studies (2014): 5(4.1) 605-610

- How can we move on our methodological (and thus also ethical) approaches to working with children and young people?

The abstracts we received reflected the diversity of contemporary childhood studies research, including both qualitative and quantitative approaches. However, we found that the articles based on qualitative research best met our criteria for inclusion in the special issue, perhaps due to the strong tradition within qualitative research of questioning data generation, analysis, and explanation (Mason, 2002). In fact, while this was not planned, several of the articles we included in the special edition deal with similar methodological approaches, but from different angles, highlighting the breadth and depth of debate when conducting qualitative research with children and young people.

The special issue opens with Marja Leena Böök and Johanna Mykkänen’s article, which looks critically at employing photo-narratives as a participatory method in family research. They discuss various tensions that occurred in their research: balancing the involvement of children and parents, power differences revealed during attempts at coconstructing data between researchers and children and young people, and complications caused by using visual data when addressing ethical issues such as informed consent and anonymity. Ulrike Zartler also writes about using photography in research with children, in her article. She focuses specifically on the process of relating children's photos with their talk about those photos. She looks at her research through a participatory lens, discussing some practical barriers to children's participation in the research, and how she attempted to address them - acknowledging that there could not be a simple resolution.

Alice Maclean and Jeni Harden then critically examine the process of conducting family group interviews. They highlight children's agency in negotiating and constructing family relationships in the interview context, challenging the assumption that children's voices are silenced when interviewed alongside their parents. They explore the challenges faced by the researcher in negotiating family dynamics, as well as relationships between researcher and participants. Sophie Sarre and Jo Moran-Ellis also reflect on the use of family interviews, in a different way. Their article looks critically at the relationship between practical issues (e.g., recruitment and gatekeeping) and epistemology, namely social constructionism. Drawing on examples from their empirical research, they argue that contradictions arising from operationalizing an epistemological standpoint can create deep potential for the researcher, revealing aspects of the phenomenon being investigated.

Marlies Kustatscher follows this by relating her attempts to move beyond a contractual model of informed consent with children in a primary school. Using a system of magnets, she attempted to re-frame consent as an ongoing process over the eightmonth course of ethnographic fieldwork. In her paper, she deconstructs the relational dynamics that complicated informed consent as she moved beyond a simple opt-in/optout model.

Susan Elsley, Michael Gallagher, and Kay Tisdall close the special issue by considering the use of digital media in research with children and young people. Drawing 
International Journal of Child, Youth, and Family Studies (2014): 5(4.1) 605-610

on cultural-social-economic and materialist approaches to understanding digital media's characteristics, they flag up both practical and ethical dilemmas, and how these overlap and inform each other. Research in digital contexts may require considerations, conversations, and collaborations with children and young people that push researchers outside of their comfort zones.

A note on terminology: The default position for the special issue is to use the phrase "children and young people”, rather than "children”. Broadly, we use the phrase "children and young people" to refer to children under the age of 18, following the UN Convention on the Rights of the Child. We invited authors to deviate from this should they have good reason, for example if their research involved young children.

\section{Closing Thoughts}

CRFR supports both established and early career researchers, and we are pleased that a mixture is represented in this special issue. As each author or group of authors unpack how their approaches to involving children and young people in research have played out in practice, some common ground emerges. In each article in the special issue there are threads of what Guillemin and Gillam (2004) call "ethics in practice” (p. 269): acknowledging and thinking through the day-to-day ethical issues that arise during research. Notably, all of the articles come from European contexts and all offer a reconsideration of the childhood studies mantras that have developed from this context.

Children and young people's participation is a clear theme: several articles specifically espouse a participatory approach, examining what that meant in practice. Others touch on the topic more implicitly, particularly in the context of involving children and young people in data analysis. Another common theme is how authors have attempted to listen to, interpret, and represent "the voice of the child" through verbal, observational, digital, and visual methods. The articles explore the concept of children and young people's agency and autonomy, when placed in the context of relationships between families and peers, and between researchers and participants themselves.

Rather than offering answers or tidy resolutions, this special issue foregrounds complexity and uncertainty. Research happens in a complicated tangle of dynamic relationships, between researcher and participants, between ethics and epistemology, between theory and practice. The articles in this special issue carve out space for open conversations about these complications in research that involves children and young people.

The Centre for Research on Families and Relationships is a consortium research center, based at the University of Edinburgh, with partners at the Universities of Aberdeen, Glasgow, Glasgow Caledonian, Highland \& Islands and Stirling. 
International Journal of Child, Youth, and Family Studies (2014): 5(4.1) 605-610

\section{References}

Alderson, P., \& Morrow, A. (2011). The ethics of research with children and young people. London: Sage Publications. http://dx.doi.org/10.4135/9781446268377

Coad, J., \& Evans, R. (2008). Reflections on practical approaches to involving children and young people in the data analysis process. Children \& Society, 22(1), 41-52. http://dx.doi.org/10.1111/j.1099-0860.2006.00062.x

Davis, J. (2009). Involving children. In E. K. M. Tisdall, J. M. Davis, \& M. Gallagher (Eds.), Researching with children and young people: Research design, methods and analysis (pp. 154-185). London: Sage Publications. http://dx.doi.org/10.4135/9781446268315

Gallacher, L., \& Gallagher, M. (2008). Methodological immaturity in childhood research? Thinking through "participatory methods”. Childhood, 15(4), 499-516. http://dx.doi.org/10.1177/0907568208091672

Guillemin, M., \& Gillam, L. (2004). Ethics, reflexivity, and "ethically important moments” in research. Qualitative Inquiry, 10(2), 261-280. http://dx.doi.org/10.1177/1077800403262360

Harden, J., Scott, S., Backett-Milburn, K., \& Jackson, S. (2000). Can’t talk, won’t talk? Methodological issues in researching children. Sociological Research Online, 5(2). Retrieved September 15, 2014, from http://www.socresonline.org.uk/5/2/harden.htm

James, A., \& Prout, A. (1997). Preface to the second edition. In A. James \& A. Prout (Eds.), Constructing and reconstructing childhood: Contemporary issues in the sociological study of childhood (pp. ix-xvii). London: Falmer Press.

Kellett, M. (2010). Small shoes, big steps! Empowering children as active researchers. American Journal of Community Psychology, 46(1/2), 195-203. http://dx.doi.org/10.1007/s10464-010-9324-y

Mannion, G. (2007). Going spatial, going relational: Why "listening to children” and children's participation needs reframing. Discourse: Studies in the Cultural Politics of Education, 28(3), 405-420. http://dx.doi.org/10.1080/01596300701458970

Mason, J. (2002). Qualitative research (2nd ed.). London: Sage Publications.

Mauthner, M. (1997). Methodological aspects of collecting data from children: Lessons from three research projects. Children \& Society, 11(1), 16-28. http://dx.doi.org/10.1111/j.1099-0860.1997.tb00003.x

Mayall, B. (2012). An afterword: Some reflections on a seminar series. Children's Geographies, 10(3), 347-355. http://dx.doi.org/10.1080/14733285.2012.693383

Percy-Smith, B. (2006). From consultation to social learning in community participation with young people. Children, Youth and Environments, 16(2), 153-179. 
International Journal of Child, Youth, and Family Studies (2014): 5(4.1) 605-610

Prout, A. (2005). The future of childhood. London: Routledge.

Prout, A. (2011). Taking a step away from modernity: Reconsidering the new sociology of childhood. Global Studies of Childhood, 1(1), 4-14. http://dx.doi.org/10.2304/gsch.2011.1.1.4

Prout, A., \& James, A. (1997). A new paradigm for the sociology of childhood? Provenance, promise and problems. In A. James \& A. Prout (Eds.), Constructing and reconstructing childhood: Contemporary issues in the sociological study of childhood (2nd ed., pp. 7-33). London: Falmer Press.

Prout, A., \& Tisdall, E. K. M. (2006). Conclusion: Social inclusion, the welfare state and understanding children's participation. In E. K. M. Tisdall, J. M. Davis, M. Hill, \& A. Prout (Eds.), Children, young people and social inclusion: Participation for what? (pp. 235-246). Bristol: The Policy Press. http://dx.doi.org/10.1332/policypress/9781861346629.003.0013

Punch, S. (2002). Research with children: The same or different from research with adults? Childhood, 9(3), 321-341. http://dx.doi.org/10.1177/0907568202009003005

Punch, S., \& Tisdall, E. K. M. (2012). Exploring children and young people's relationships across minority worlds. Children's Geographies, 10(3), 241-248. http://dx.doi.org/10.1080/14733285.2012.693375

Thomson, F. (2007). Are methodologies for children keeping them in their place? Children’s Geographies, 5(3), 207-218. http://dx.doi.org/10.1080/14733280701445762

United Nations Committee on the Rights of the Child. (2009). General comment no. 12: The right of the child to be heard. Office of the United Nations High Commissioner for Human Rights [online]. Retrieved March 19, 2013, from http:www2.ohcr.org/English/bodies/crc/comments.html

Uprichard, E. (2008). Children as "being and becomings": Children, childhood and temporality. Children \& Society, 22(4), 303-313. http://dx.doi.org/10.1111/j.1099-0860.2007.00110.x

Woodgate, R. (2001). Adopting the qualitative paradigm to understanding children's perspectives of illness: Barrier or facilitator? Journal of Pediatric Nursing, 16(3), 149-161. http://dx.doi.org/10.1053/jpdn.2001.24178 